\title{
Nota
}

\section{DEFICIENCY SYMPTOMS AND UPTAKE OF MICRONUTRIENTS BY CASTOR BEAN GROWN IN NUTRIENT SOLUTION(1)}

\author{
José Lavres Junior(2), Cleusa Pereira Cabral(3), Mônica Lanzoni \\ Rossi $^{(4)}$, Thiago Assis Rodrigues Nogueira( ${ }^{(5)}$, Neusa de Lima Nogueira( ${ }^{(6)}$ \\ \& Eurípedes Malavolta ${ }^{(7) \dagger}$
}

\begin{abstract}
SUMMARY
Castor bean is a nutrient-demanding species, but there is still little information on its micronutrient requirements. The objectives of this study were

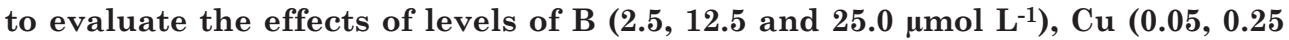
and $\left.0.50 \mu \mathrm{mol} \mathrm{L} \mathrm{L}^{-1}\right), \mathrm{Mn}\left(0.2,1.0\right.$ and $\left.2.0 \mu \mathrm{mol} \mathrm{L}^{-1}\right)$ and $\mathrm{Zn}\left(0.2,1.0\right.$ and $\left.2.0 \mu \mathrm{mol} \mathrm{L} \mathrm{L}^{-1}\right)$ in a nutrient solution on plant $\mathrm{B}, \mathrm{Cu}, \mathrm{Mn}$ and $\mathrm{Zn}$ concentrations and uptake, vegetative growth and fruit yield of castor bean "Iris", grown in greenhouse. The experiment was arranged in a completely randomized block design with three replicates. The first deficiency symptoms were observed for $\mathrm{B}$, followed by $\mathrm{Zn}, \mathrm{Cu}$ and $\mathrm{Mn}$. The main changes in the cell ultrastructure due to lack of $\mathrm{B}$ were thickening of the cell walls and middle lamellae, distorted chloroplasts and tightly stacked thylakoids, besides the absence of starch grains. The Mn, Zn and $\mathrm{Cu}$ deficiencies led to disruption of chloroplasts, disintegration of thylakoids and absence of amyloplasts. The concentration and uptake of $\mathrm{B}, \mathrm{Cu}, \mathrm{Mn}$, and $\mathrm{Zn}$ in castor bean plants increased with micronutrient supply in the solution. Fruit yield was drastically reduced by $B$ and Mn deficiencies. On the other hand, the dry matter yield of the shoot and root of castor bean plants was not. In the treatment with full nutrient solution, the leaves accumulated 56 and $48 \%$ of the total $B$ and Mn taken up by the plants, respectively, and the seeds and roots 85 and $61 \%$ of the total $\mathrm{Cu}$ and $\mathrm{Zn}$ taken up, respectively. This shows the high demand of castor bean Iris for B and Mn for fruit yield.
\end{abstract}

Index terms: nutritional requirement, Ricinus communis $\mathrm{L}$, cell ultrastructure.

\footnotetext{
(1) Recebido para publicação em 28 de maio de 2010 e aprovado em 11 de novembro de 2011.

(2) Professor Doutor do Centro de Energia Nuclear na Agricultura, Universidade de São Paulo, Laboratório de Nutrição Mineral de Plantas - CENA/USP. Caixa Postal 96. Av. Centenário 303, CEP 13400-970 Piracicaba (SP). E-mail: jlavres@cena.usp.br

(3) Bióloga do Laboratório de Nutrição Mineral de Plantas, CENA/USP. E-mail: cpcabral@cena.usp.br

(4) Bióloga do Laboratório de Histopatologia e Biologia Estrutural de Plantas, CENA/USP. E-mail: monicalr@cena.usp.br

(5) Doutorando do Programa de Pós-graduação em Química na Agricultura e no Ambiente do CENA/USP. Bolsista FAPESP. E-mail: tarnogueira@gmail.com

(6) Professora Doutora do Centro de Energia Nuclear na Agricultura, CENA/USP. Laboratório de Histopatologia e Biologia Estrutural de Plantas. Piracicaba (SP). E-mail: nogueira@cena.usp.br

(7) In memoriam.
} 


\title{
RESUMO: SINTOMAS DE DEFICIÊNCIA E ACÚMULO DE MICRONU- TRIENTES NA MAMONEIRA CULTIVADA EM SOLUÇÃO NUTRITIVA
}

\begin{abstract}
A mamoneira é uma espécie exigente em nutrientes, porém ainda há pouca informação acerca da demanda por micronutrientes. Objetivou-se com este estudo avaliar os

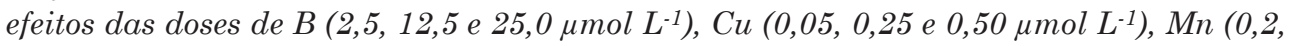
1,0 e 2,0 $\left.\mu \mathrm{mol} \mathrm{L} \mathrm{L}^{-1}\right)$ e Zn (0,2, 1,0 e 2,0 $\mu \mathrm{mol} \mathrm{L^{-1 } )}$ nos teores e acúmulos desses elementos, no crescimento vegetativo e na produção de frutos da mamoneira Iris cultivada em casa de vegetação. O delineamento experimental foi o de blocos completos ao acaso, com três repetições. As primeiras manifestações de deficiência foram observadas em $B$, seguidas das de $\mathrm{Zn}$, Cu e Mn. As principais alterações nas ultraestruturas celulares na carência de B foram o espessamento da parede celular e lamela média, a distorção no formato dos cloroplastos, com tilacoides muito agrupados, além da ausência de grãos de amido. As carências de $\mathrm{Mn}$, Zn e Cu provocaram alterações nas conformações dos cloroplastos, desestruturação dos tilacoides e ausência de amiloplastos. Os teores e os acúmulos de B, Cu, Mn e Zn aumentaram com o incremento da concentração desses elementos na solução nutritiva. $A$ produção de frutos foi drasticamente reduzida com as carências de B e Mn. Por outro lado, a produção de parte aérea e de raizes não foi alterada pelos tratamentos. No tratamento completo, as folhas acumularam 56 e $48 \%$ do total de B e Mn absorvidos pelas plantas, respectivamente. Já as sementes e as raízes da mamoneira Iris acumularam 85 e $61 \%$ do total de $\mathrm{Cu}$ e $\mathrm{Zn}$ absorvidos, respectivamente. A mamoneira Iris mostrou-se exigente em $B$ e Mn para a produção de frutos.
\end{abstract}

Termos de indexação: exigência nutricional, Ricinus communis L, ultraestrutura celular.

\section{INTRODUCTION}

Castor bean (Ricinus communis L.) is grown in the Brazilian Cerrado (savanna) in rotation with soybean and in the country's semi-arid Northeast region in consortium with other crops, mainly cowpea and corn (Azevedo et al., 2007), as a means to diversify the income source of farmers. However, this oilseed plant is often grown in marginal areas, with a series of soil fertility limitations (Lima et al., 2007). In this respect, fertilization has been reported to increase the biomass production and yield of seeds and oil (Severino et al., 2006; Sahrawat et al., 2010).

Regarding soil fertility, many studies on temporary and perennial crops in Brazil report the low availability of micronutrients and favorable response to their application. Among the micronutrients, B and $\mathrm{Zn}$ have a greater relative frequency of deficiency, limiting the production of many crops (Malavolta et al., 2006). Therefore, in view of the growing need to ensure adequate supply of food, fiber and renewable energy for the expanding human population, a more efficient land management is essential, including the application of fertilizers and soil amendments and adequate soil and water management practices (Malavolta et al., 2006). In this context, an efficient fertilizer use is important to boost crop yields, which can be increased by up to $60 \%$ (Stewart et al., 2005; Vitousek et al., 2009; Taylor \& Townsend, 2010). Increased yields may translate into less planted area and consequently lower environmental impact, as well as lower food prices (Paterniani, 2001).

Studies of castor bean fertilization in Brazil have mainly focused on the nutrients $\mathrm{N}, \mathrm{P}$ and $\mathrm{K}$ (Severino et al., 2006; Silva et al., 2007; Almeida Jr. et al., 2009; Diniz Neto et al., 2009). Few studies have investigated the nutritional state of the castor plant underlying the requirements determined for minerals, notably micronutrients (Hocking, 1982; Lange et al., 2005; Chiaradia et al., 2009). In this sense, studies of the nutrient uptake process (Nakagawa \& Neptune, 1971) and on critical nutrient levels and nutrient exportation, underlying knowledge of the nutritional demands of this crop, are fundamental to determine adequate fertilization recommendations.

The purpose of this study was to assess the effects of levels of $\mathrm{B}, \mathrm{Cu}, \mathrm{Mn}$ and $\mathrm{Zn}$ on visible deficiency symptoms, ultrastructural alterations of cells of the leaf mesophyll, the distribution of micronutrients among the plant organs and the dry matter yield in the shoot, roots and fruits (capsules plus seeds) of the bean castor hybrid for commercial production "Iris".

\section{MATERIAL AND METHODS}

The experiment was carried out in a greenhouse in Piracicaba, State of São Paulo, Brazil, with the commercial of Ricinus communis L. hybrid "Iris". 
The seeds were initially placed to germinate on shallow trays containing vermiculite, moistened with a $\mathrm{CaSO}_{4}, 0.1 \mathrm{mmol} \mathrm{L}^{-1}$. When the plantlets reached a height of about $5 \mathrm{~cm}$ (19 days after sowing), they were transferred to plastic trays with capacity of $40 \mathrm{~L}$ containing a slightly modified Epstein \& Bloom (2005) nutrient solution, diluted to $1 / 5$ of the normal level. The plants were fixed at $2 \mathrm{~cm}$ above the plant root collar with plastic foam. Eight days after this transplantation, the plants were again transplanted to start the treatments, using one plant per pot $(1.5 \mathrm{~L})$ lined with $\mathrm{Al}$ foil, containing $1 \mathrm{~L}$ of the nutrient solution. During the experiment, the nutrient solutions, under constant aeration, were replenished every 15 days and the volume in each pot was complemented daily with deionized water. At the time of the first nutrient solution replenishment (eight days after transplantation to the nutrient solution diluted to $1 / 5$ of the normal level), the lowest levels were omitted - absence of $\mathrm{B}, \mathrm{Cu}, \mathrm{Mn}$ and $\mathrm{Zn}$ in the solution - with the aim of aggravating the deficiency symptoms. The initial $\mathrm{pH}$ of the solution was 5.5.

The complete nutrient solution, modified from that of Epstein \& Bloom (2005), had the following composition: $16.0 \mathrm{mmol} \mathrm{L}^{-1} \mathrm{~N} ; 6.0 \mathrm{mmol} \mathrm{L}^{-1} \mathrm{~K}$; $4.0 \mathrm{mmol} \mathrm{L}-1 \mathrm{Ca} ; 2.0 \mathrm{mmol} \mathrm{L}-1 \mathrm{P} ; 1.0 \mathrm{mmol} \mathrm{L}^{-1} \mathrm{Mg}$; $1.0, \mathrm{mmol} \mathrm{L}^{-1}$ of S; $20.0 \mu \mathrm{mol} \mathrm{L}^{-1} \mathrm{Fe} ; 50.0 \mu \mathrm{mol} \mathrm{L}-1$ $\mathrm{Cl} ; 25.0 \mu \mathrm{mol} \mathrm{L}^{-1} \mathrm{~B} ; 2.0 \mu \mathrm{mol} \mathrm{L}-1 \mathrm{Mn} ; 2.0 \mu \mathrm{mol} \mathrm{L}-1$ $\mathrm{Zn} ; 0.50 \mu \mathrm{mol} \mathrm{L}^{-1} \mathrm{Cu} ; 0.5 \mu \mathrm{mol} \mathrm{L}-1$ Mo (Lange et al., 2005; Lavres Jr et al., 2009). The experiment was arranged in a completely randomized block design with three replicates of the complete nutrient solution $\left(25.0 \mu \mathrm{mol} \mathrm{L}^{-1} \mathrm{~B} ; 0.50 \mu \mathrm{mol} \mathrm{L}{ }^{-1} \mathrm{Cu}\right.$ and $2.0 \mu \mathrm{mol} \mathrm{L}-1 \mathrm{Mn}$ and $\mathrm{Zn}$ ) and of the levels: 2.5 and $12.5 \mu \mathrm{mol} \mathrm{L} \mathrm{L}^{-1} \mathrm{~B} ; 0.05$ and $0.25 \mu \mathrm{mol} \mathrm{L}-1 \mathrm{Cu} ; 0.2$ and $1.0 \mu \mathrm{mol} \mathrm{L}{ }^{-1} \mathrm{Mn}$ and 0.2 and $1.0 \mu \mathrm{mol} \mathrm{L}^{-1} \mathrm{Zn}$.

Forty-nine days after the start of the treatments, the plants grown at the lowest $\mathrm{B}$ level were harvested and separated in roots, stems, lower leaves (without marked symptoms) and upper leaves (with moderate to marked symptoms). The same procedure was carried out on the $70^{\text {th }}$ day for the other treatments. On that occasion, the fruits were collected and later separated into capsules and seeds. The labeled material was placed in paper bags and dried in a drying chamber at $65{ }^{\circ} \mathrm{C}$ for $72 \mathrm{~h}$. The material was weighed and ground in a Wiley mill (mesh $1.00 \mathrm{~mm}$ ) to assess the chemical composition of the plant tissues, according to Malavolta et al. (1997).

The uptake of $\mathrm{B}, \mathrm{Cu}, \mathrm{Mn}$ and $\mathrm{Zn}$ in the tissues was calculated by multiplying the level by the dry matter weight. The translocation of the elements was determined in function of the uptake in the shoot divided by the total amount absorbed and multiplied by 100. For the nutrient distribution among the plant parts, the quantity in each part was determined by dividing the amount accumulated in the specific part by the total amount absorbed and multiplying by 100 .

For the transmission electron microscopy (TEM) study, a parallel experiment was conducted, using growing procedures described by Lange et al. (2005). However, the micronutrient of interest was omitted to aggravate the deficiency symptoms. Then at the time of collecting the tissues, the leaf blades that showed the strongest deficiency symptoms were chosen for each nutrient. These leaf samples (measuring approximately $1 \times 2 \mathrm{~mm}$ ) were fixed in a modified Karnovsky solution (2\% glutaraldehyde, $4 \%$ paraformaldehyde, $5 \mathrm{mmol} \mathrm{L}^{-1}$ of calcium chloride in $0.1 \mathrm{~mol} \mathrm{~L}^{-1}$ of sodium cacodylate buffer, $\mathrm{pH}$ 7.2) for $48 \mathrm{~h}$ at $4{ }^{\circ} \mathrm{C}$, washed with $0.1 \mathrm{~mol} \mathrm{~L}^{-1}$ of sodium cacodylate buffer ( $3 \times 15 \mathrm{~min}$.) and then fixed for $1 \mathrm{~h}$ with $1 \%$ osmium tetraoxide in $0.2 \mathrm{~mol} \mathrm{~L}^{-1}$ of sodium cacodylate buffer. After rapid washing in a $0.9 \%$ saline solution, they were stained en bloc with $2.5 \%$ uranyl acetate in water overnight at $4{ }^{\circ} \mathrm{C}$. The samples were then dehydrated in a graded acetone series in water $(25,50,75,90$, and $100 \%)$ and embedded in Epon 812 or Spurr resin, according to Luft (1961), and cut in ultrafine (60-90 nm) sections.

The sections were deposited on copper screens covered with collodion, contrasted with $2.5 \%$ uranyl acetate and lead citrate, as described by Reynolds (1963), and were then examined under a Zeiss EM900 electron microscope at $50 \mathrm{kV}$ at amplification of 3,000 and $4,400 \mathrm{x}$.

The results were statistically analyzed using the SAS program (SAS, 2000). Analysis of variance was performed and the significance determined by the F-test, the Tukey test to compare the means $(p<0.05)$ and polynomial regression to compare the effects of the treatments.

\section{RESULTS AND DISCUSSION}

The visual symptoms of the deficiencies of the micronutrients were observed in the treatments at different times. The first sign of deficiency was observed in the plants maintained in the solution with the lowest $\mathrm{B}$ and $\mathrm{Zn}$ levels 28 days after the beginning of the treatments, followed by that with the lowest $\mathrm{Cu}$ level, 33 days later and 35 days later for Mn.

The plants grown in the solution with the lowest B level showed malformation and curling of the newest leaf blades. The other new leaves had a leathery and stunted appearance. The edges of the newest leaves (leaf lobes) showed necrosis and some plants had clusters of underdeveloped and darkened fruits. All plants were smaller than those grown in complete solution (not deficient in 
B). The ultrastructural analyses mainly permitted identifying thickening of the cell walls and middle lamellae, significant presence of mitochondria in the protoplasm and distorted chloroplasts without the presence of grana (thylakoids), besides the absence of amyloplasts containing starch grains (Figure 1a).

Boron is involved in plant growth, more specifically in the differentiation of tissue and synthesis and lignification of the cell wall (90\% of the B in cells is in their walls) and in the metabolism of phenolic compounds, among other roles (Loomis \& Durst, 1992). The morphological changes in plants caused by $\mathrm{B}$ deficiency may be due to the accumulation of indol-3-aceitc acid (IAA), resulting in IAA oxidase inhibition because of phenol compounds such as chlorogenic acid and caffeic acid. The association of B with some phenolic compounds, e.g., caffeic acid, blocks the formation of quinones, favoring the synthesis of phenolic alcohols that are precursors of lignin. On the other hand, there is the possibility of reduction of the IAA levels in plants in which biosynthesis of caffeic acid does not occur, due to the increased activity of polyphenol oxidase (which oxidizes the IAA substrate), therefore impeding collaboration with $\mathrm{Ca}$ in diminishing the cell wall rigidity (Gupta, 2001; Malavolta, 2006). In turn, the absence of starch grains can be partly explained by the interruption of carbohydrate synthesis due to inhibition of the phosphorylase action (e.g., formation of ATP during photosynthesis) or reduction of the synthesis of uracil nucleotides, the main constituent of RNA and also a precursor of uridine diphosphate glucose (Marschner, 1995; Mengel \& Kirkby, 2001). This series of events, in turn, results in the visual manifestation of nutritional deficiency.

The plants grown at the lowest $\mathrm{Cu}$ level showed curled blades of the newest leaves, with dark green color and some clear spots evolving to necrotic and coalescent points, mainly located at the ends of the leaf lobes. The electromicrographs particularly revealed the disorganization of the chloroplasts, in which it was possible to observe disorganized stacks of thylakoids (grana), besides the absence of amyloplasts (with starch grains) (Figure 1b). This is in agreement with the observations reported by Baron et al. (1995). On the other hand, there was no increased presence of mitochondria, as found under B deficiency. According to Yreula (2009), $\mathrm{Cu}$-deficient leaf tissues are less efficient in electron transport in photosytems I and II (PSI and PSII), due to the decreased biosynthesis of plastocyanin and plastoquinone, negatively affecting photosynthesis. The impaired photosynthesis process results in an excess of electrons $\left(\mathrm{P} 680^{+}\right)$, which are diverted to production of reactive oxygen species (ROS). In turn, the disorganization of the thylakoid membranes is associated with the lower activity of $\mathrm{Cu} / \mathrm{Mn} /$ Zn-superoxide dismutase, which catalyzes the dismutation of superoxide (oxygen-reactive species, $\left.\mathrm{O}_{2}^{-}\right)$into oxygen $\left(\mathrm{O}_{2}\right)$ and hydrogen peroxide $\left(\mathrm{H}_{2} \mathrm{O}_{2}\right)$ (Smirnoff, 2005). In general, the typical symptoms of $\mathrm{Cu}$ deficiency first appear in the newest tissues and then spread to the entire leaf blade. In this study, it was observed that the leaves can also be curled or otherwise malformed, and can be chlorotic (loss of chlorophyll) or even necrotic, aside from a reduction in the plant biomass (Table 1).

At the lowest Mn level, the newest leaf blades and new leaves of the lateral ramifications showed symptoms characteristic of Mn deficiency (interneval chlorosis with darker colored areas near the veins). The fruit color was lighter than of the plants grown in complete solution. The Mn concentrations in these tissues are presented in table 2. Regarding ultrastructural alterations, the Mn deficiency resulted in an absence of amyloplasts (with starch grains) in the chloroplasts along with stunted chloroplasts, thylakoids arranged in tight bundles (grana), located very near each other in the stroma. There were also vesicles in the cytoplasm

Table 1. Dry matter yield of the parts of the castor bean hybrid "Iris", grown in a complete nutrient solution and with different levels of $\mathrm{B}, \mathrm{Cu}, \mathrm{Mn}$ and $\mathrm{Zn}$

\begin{tabular}{|c|c|c|c|c|c|}
\hline Treatment & Root & Shoot & Capsule & Seed & Fruit \\
\hline$\mu \mathrm{mol} \mathrm{L}-1$ & & & $\mathrm{~g} / \mathrm{plant}$ & & ـ \\
\hline Complete & $6.9 \mathrm{ab}$ & $15.7 \mathrm{a}$ & $6.6 \mathrm{a}$ & $13.3 \mathrm{a}$ & $19.9 \mathrm{a}$ \\
\hline $\mathrm{B}-2.5$ & $6.7 \mathrm{ab}$ & $13.7 \mathrm{a}$ & - & - & $0.3 \mathrm{~d}$ \\
\hline $\mathrm{B}-12.5$ & $7.1 \mathrm{ab}$ & $17.2 \mathrm{a}$ & $5.6 \mathrm{abc}$ & $12.8 \mathrm{a}$ & $18.4 \mathrm{ab}$ \\
\hline $\mathrm{Cu}-0.05$ & $6.1 \mathrm{ab}$ & $12.9 \mathrm{a}$ & $5.6 \mathrm{abc}$ & $9.5 \mathrm{ab}$ & $15.1 \mathrm{abc}$ \\
\hline $\mathrm{Cu}-0.25$ & $7.4 \mathrm{ab}$ & $12.4 \mathrm{a}$ & $6.3 \mathrm{ab}$ & $11.6 \mathrm{ab}$ & $17.9 \mathrm{ab}$ \\
\hline $\mathrm{Mn}-0.2$ & $4.5 \mathrm{~b}$ & $11.4 \mathrm{a}$ & $3.1 \mathrm{c}$ & $5.9 \mathrm{~b}$ & $9.0 \mathrm{c}$ \\
\hline $\mathrm{Mn}-1.0$ & $5.9 \mathrm{ab}$ & $14.4 \mathrm{a}$ & $4.6 \mathrm{bc}$ & $11.8 \mathrm{ab}$ & $16.4 \mathrm{ab}$ \\
\hline $\mathrm{Zn}-0.2$ & $9.4 \mathrm{a}$ & $16.0 \mathrm{a}$ & $4.3 \mathrm{bc}$ & $8.2 \mathrm{ab}$ & $12.5 \mathrm{bc}$ \\
\hline $\mathrm{Zn}-1.0$ & $6.0 \mathrm{ab}$ & $15.8 \mathrm{a}$ & $4.7 \mathrm{bc}$ & $10.5 \mathrm{ab}$ & $15.2 \mathrm{bc}$ \\
\hline CV (\%) & 19.1 & 22.2 & 19.4 & 20.6 & 17.2 \\
\hline
\end{tabular}

Means followed by the same letters are not significantly different by the Tukey's test at $\mathrm{p}<0.05$. 
Table 2. Cupper, Mn and Zn concentration (y) in parts of the castor bean hybrid "Iris", grown in a complete nutrient solution and with different levels of $\mathrm{Cu}$, Mn and $\mathrm{Zn}$ (x)

\begin{tabular}{|c|c|c|c|c|c|c|}
\hline Level & Root & Stem & Lower Leaf & Upper Leaf & Capsule & Seed \\
\hline \multirow[t]{2}{*}{$\mu \mathrm{mol} \mathrm{L}-1$} & \multicolumn{6}{|c|}{$-\mathrm{mg} \mathrm{kg}^{-1}$} \\
\hline & \multicolumn{6}{|c|}{ Copper } \\
\hline 0.05 & 4.4 & 4.1 & 2.7 & 2.3 & 0.9 & 3.5 \\
\hline 0.25 & 15.4 & 6.5 & 3.3 & 4.4 & 0.7 & 8.7 \\
\hline 0.50 & 24.8 & 5.9 & 3.9 & 5.2 & 2.2 & 11.4 \\
\hline CV (\%) & 5.0 & 16.0 & 18.4 & 17.1 & 11.3 & 2.4 \\
\hline Equation & $\hat{\mathrm{y}}=1.11+67.17^{* * \mathrm{x}} \mathrm{x}-39.67^{* *} \mathrm{x}^{2}$ & $\hat{y}=-0.04+5.99^{* *} \mathrm{x}$ & $\hat{\mathrm{y}}=2.54+2.84^{* * \mathrm{x}}$ & $\hat{y}=1.57+15.26^{*} \mathrm{x}-15.92^{*} \mathrm{x}^{2}$ & $\hat{y}=1.07-5.06^{* *} x+13.67^{* *} x^{2}$ & $\hat{y}=1.86+35.32^{* *} x-32.62^{* *} x^{2}$ \\
\hline \multirow[t]{2}{*}{$\mathrm{R}^{2}$} & $0.99^{* *}$ & $0.94^{* *}$ & $0.83^{* *}$ & $0.87^{* *}$ & $0.98^{* *}$ & $0.99^{* * *}$ \\
\hline & \multicolumn{6}{|c|}{ Manganese } \\
\hline 0.20 & 7.9 & 2.5 & 14.8 & 13.0 & 4.4 & 4.2 \\
\hline 1.00 & 12.0 & 8.2 & 29.3 & 26.0 & 9.3 & 16.7 \\
\hline 2.00 & 35.5 & 12.4 & 66.5 & 48.6 & 18.3 & 23.1 \\
\hline CV (\%) & 10.6 & 10.7 & 7.2 & 9.0 & 7.2 & 3.1 \\
\hline Equation & $\hat{y}=8.63-5.69^{*} x+9.06^{* *} x^{2} \quad \hat{y}=$ & $=0.68+9.23^{* *} \mathrm{x}-1.69^{*} \mathrm{x}^{2}$ & $\hat{\mathrm{y}}=14.39+10.92^{*} \mathrm{x}+8.39^{*} \mathrm{x}^{2}$ & $\hat{\mathrm{y}}=8.50+18.71^{* *} \mathrm{x}$ & $\hat{y}=4.45+1.75^{*} x+2.58^{*} x^{2}$ & $\hat{y}=-0.82+24.34^{* *} x-6.18^{* *} x^{2}$ \\
\hline \multirow[t]{2}{*}{$\mathrm{R}^{2}$} & $0.96^{* *}$ & $0.97^{* *}$ & $0.94^{* *}$ & $0.96^{* *}$ & $0.98^{* *}$ & $0.97^{* *}$ \\
\hline & \multicolumn{6}{|c|}{ Zinc } \\
\hline 0.20 & 16.1 & 15.6 & 24.9 & 25.7 & 15.3 & 18.7 \\
\hline 1.00 & 40.5 & 18.1 & 57.8 & 48.4 & 35.9 & 55.1 \\
\hline 2.00 & 62.3 & 19.6 & 25.9 & 59.2 & 21.7 & 47.2 \\
\hline CV $(\%)$ & 4.6 & 8.6 & 3.3 & 5.9 & 2.6 & 4.7 \\
\hline Equation & $\hat{y}=12.87+24.90^{* *} x$ & $\hat{y}=13.66+1.65^{*} \mathrm{x}$ & $\hat{y}=8.53+89.88^{* *} x-40.60^{* *} x^{2}$ & $\hat{y}=17.52+43.15^{* *} x-11.43^{* *} x^{2}$ & $\hat{y}=5.89+51.38^{* *} x-21.32^{* *} x^{2}$ & $\hat{\mathrm{y}}=4.8374 .88^{* *} \mathrm{x}-26.84^{* *} \mathrm{x}^{2}$ \\
\hline $\mathrm{R}^{2}$ & $0.98^{* *}$ & $0.42^{*}$ & $0.99^{* *}$ & $0.99 * *$ & $0.97^{* *}$ & $0.97^{* *}$ \\
\hline
\end{tabular}

**: Significant at $\mathrm{p}<0.01$. ${ }^{*}$ Significant at $\mathrm{p}<0.05$. ns: not significant.

(Figure 1c), confirming the disorganization of the plant photosynthesis apparatus and impeding the reactions of $\mathrm{CO}_{2}$ fixation for carbohydrate production, since over $80 \%$ of the Mn contained in the chloroplasts is involved in the electron transport in photosystem II (PS-II). These changes in the chloroplast ultrastructure were also observed by Lavres Jr. et al. (2010) in soybean plants and by Papadakis et al. (2007) in citrus plants.

The plants grown in the solution with the lowest level of Zn were substantially affected by necrosis at the apex, which occurred during the entire sprouting. The newest leaves were smaller, and all lobes dead. The other recently expanded leaves showed interneval chlorosis across the blade. The plants were stunted and had a high number of lateral ramifications. The electron microscopic images revealed enlarged chloroplasts in which the thylakoids were stacked tightly in bundles (grana) very near to each other in the stroma - as also observed for Mn-deficient plants - with a higher number of vesicles in the cytoplasm (Figure 1d). There was also an absence of amyloplasts in the chloroplasts of Zn-deficient leaf blades. The plants receiving the complete treatment (Figure 1e) had well-distributed chloroplasts in the cytosol, amyloplasts containing starch grains, well-defined cell nuclei and a large cytoplasm area.

It is known that oxygen-reactive species $\left(\mathrm{O}_{2}{ }^{-}\right)$ occur preferentially in the chloroplasts and that the thylakoids are the main target of oxidative damage. Low $\mathrm{Zn}$ levels can increase the production of superoxide radicals $\left(\mathrm{O}_{2}^{-}\right)$during the photosynthetic transport of electrons, and this increased formation of singlet $\mathrm{O}_{2}$ can cause severe damage to the thylakoid membranes, reducing the $\mathrm{CO}_{2}$ assimilation rate, mainly in genotypes with low Zn use efficiency (Chen et al., 2008). Zinc is also involved in the synthesis of tryptophan, the amino acid precursor of indol-3aceitc acid (IAA), a phytohormone responsible for plant growth. Zinc deficiency results in low levels of auxin, probably due to the greater activity of IAA oxidase (Malavolta, 2006). $\mathrm{Zn}$ is also involved in the activity of the enzyme RNA-polymerase, which hydrolyzes RNA, causing reduced protein synthesis and affecting cell multiplication, meaning fewer cells with smaller sizes, in turn explaining the reduced internode length (Marschner, 1995; Mengel \& Kirkby, 2001; Malavolta, 2006).

However, Lange et al. (2005) found no $\mathrm{Cu}$ and Zn deficiency symptoms in the cultivar Iris and 

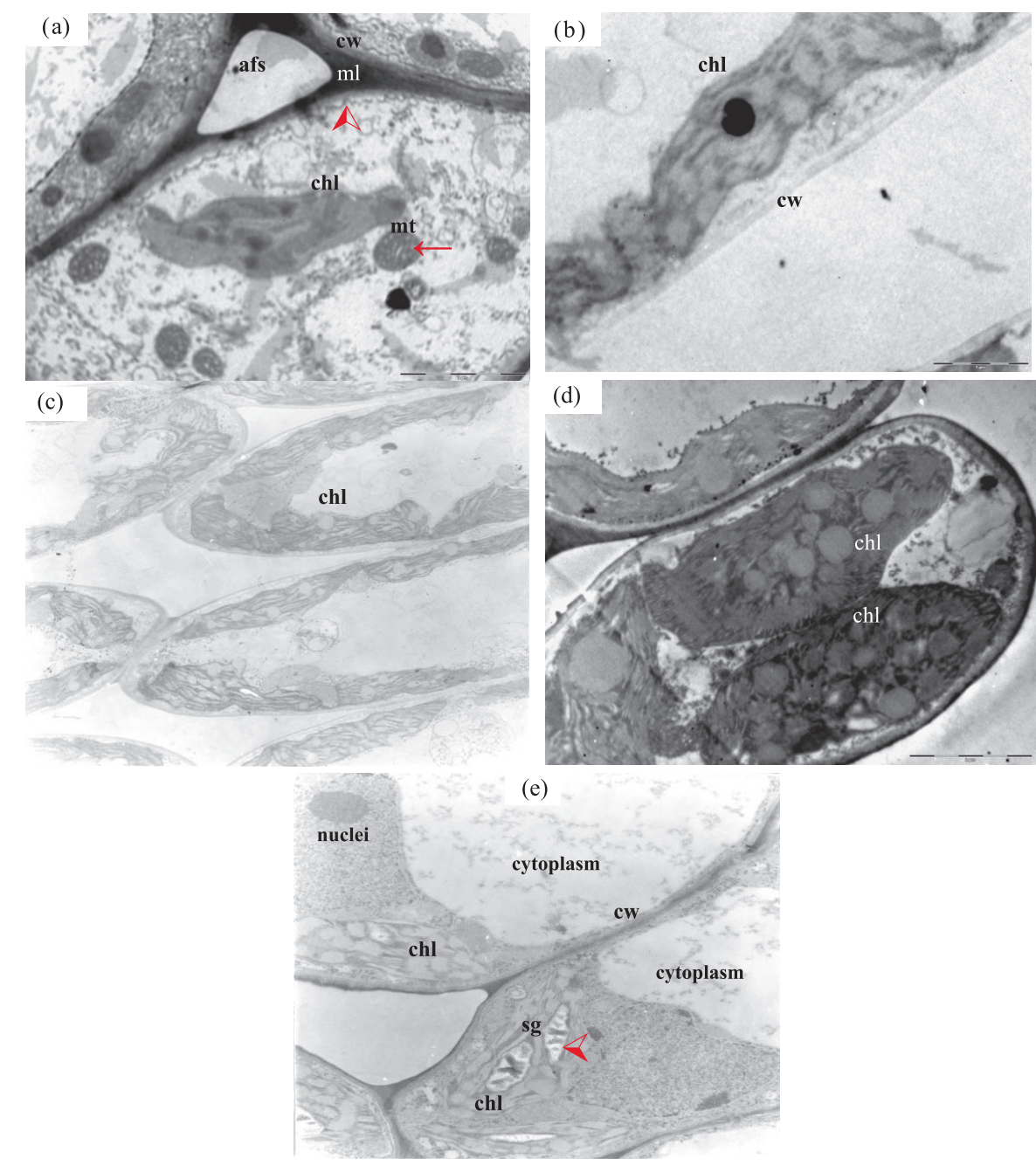

Figure 1. Transmission electron microscopy images of cells of the leaf mesophyll of the castor bean hybrid "Iris": (a) plant cells (x 3,000) grown in a nutrient solution without boron, showing chloroplasts (chl) with reduced and stacked thylakoids (grana), mitochondria (mt), thickened middle lamellae (ml) and cell wall (cw), apparent free space (afs); (b) plant cells (x 4,400) grown in a nutrient solution without copper; (c) plant cells (x 3,000) grown in a nutrient solution without manganese; (d) plant cells $(x) 3,000)$ grown in a nutrient solution without zinc; and (e) plant cells (x 3,000) grown in a complete nutrient solution, showing starch grains (sg), well organized nuclei and chloroplasts (chl) well distributed in the cytoplasm. Cells with well-defined walls and middle lamellae. The scale of the electromicrographs is $2 \mu \mathrm{m}$ (except Figure 1(c) and (e), in which it is $1 \mu \mathrm{m})$.

concluded that the absence of these symptoms was probably associated with the initial accumulation, when the plants grew in the complete diluted nutrient solution for 23 days, as well as with the mobilization of these nutrients stored in the seeds.

Dry matter yield of the root and shoot of castor bean plants was not affected by the treatments, although the plants grown in the complete nutrient solution and those deficient in B and Zn differed in height (data not shown). On average, the production of dry matter of the shoot was $53 \%$ greater than that of the root, resulting in an average shoot:root ratio of $2: 1$, which may be characteristic of the "Iris" genotype, bred to be short.
With respect to fruit yield (capsules and seeds), the plants at the lowest B and Mn levels produced lower yields than those grown in the complete solution, and $\mathrm{B}$ was the most limiting nutrient (Table 1). At a B level of $2.5 \mu \mathrm{mol} \mathrm{L} \mathrm{L}^{-1}$, the dry matter yield of the fruits was $98 \%$ lower than of the plants grown in the complete solution. These plants were harvested 21 days before those in the other treatments, due to the very severe symptoms and because they started to die back. Under this condition, the fruits were completely underdeveloped or even dead and shriveled. For the plants grown at the lowest concentration of $\mathrm{Mn}, \mathrm{Zn}$ and $\mathrm{Cu}$, the fruit production was 55, 37 and $24 \%$ lower than of those receiving the complete solution, respectively. 
In the complete treatment, the dry mass of the fruits was 21 and $188 \%$ greater than of the shoot and root, respectively, characterizing the high fruit biomass production of "Iris" when grown under adequate nutrient supply, thus making the fruits a strong sink in the partition of photoassimilates (Table 1 and Figure 2).

Therefore, among the micronutrients studied, boron was the most required by "Iris" for fruit yield, demonstrating the importance of this nutrient in the reproductive phase (fruiting). Because of the influence of $\mathrm{B}$ on the germination of pollen grains and growth of pollen tubes, it makes sense that the shortage of this nutrient severely reduces the castor fruit yield. According to Gupta (2001), plants can grow normally under moderate B deficiency, but the fruit yield is drastically affected. Lange et al.
(2005) reported that in the case of absence of B and $\mathrm{Mn}$ in the nutrient solution, the dry matter yield of the shoot was $20 \%$ lower in relation to the complete treatment. Those authors also found that in the treatments with lack of $\mathrm{Cu}$ as well as of $\mathrm{Zn}$, the total dry matter yield (root plus shoot) was not affected, in line with the absence of visual deficiency signs (visual diagnosis).

The levels of $\mathrm{Cu}, \mathrm{Mn}$ and $\mathrm{Zn}$ in the plant parts were influenced by the treatments (Table 2). The highest $\mathrm{Cu}$ concentrations were found in the root for all levels of this micronutrient in the solution, while the fruit capsules contained the lowest levels. For $\mathrm{Mn}$, the lower leaves contained the highest concentrations of this element for all Mn levels in the solution, while the concentrations were lowest in the capsules and seeds. As for Mn, the highest Zn
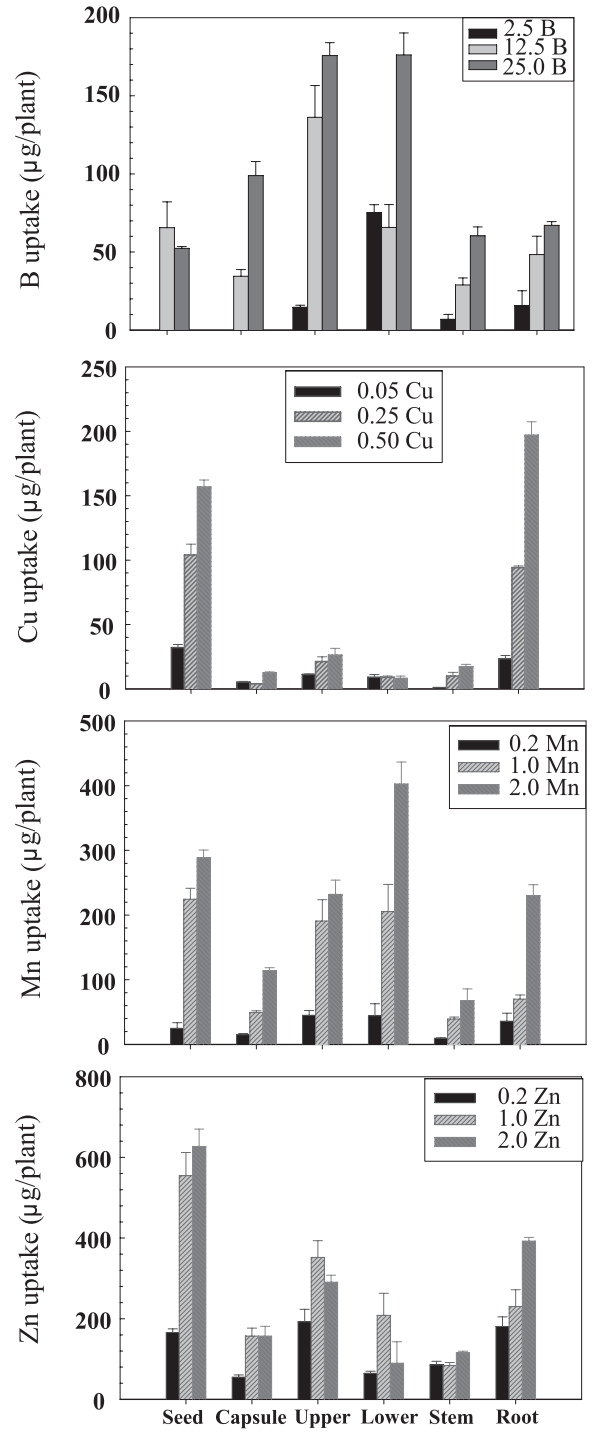
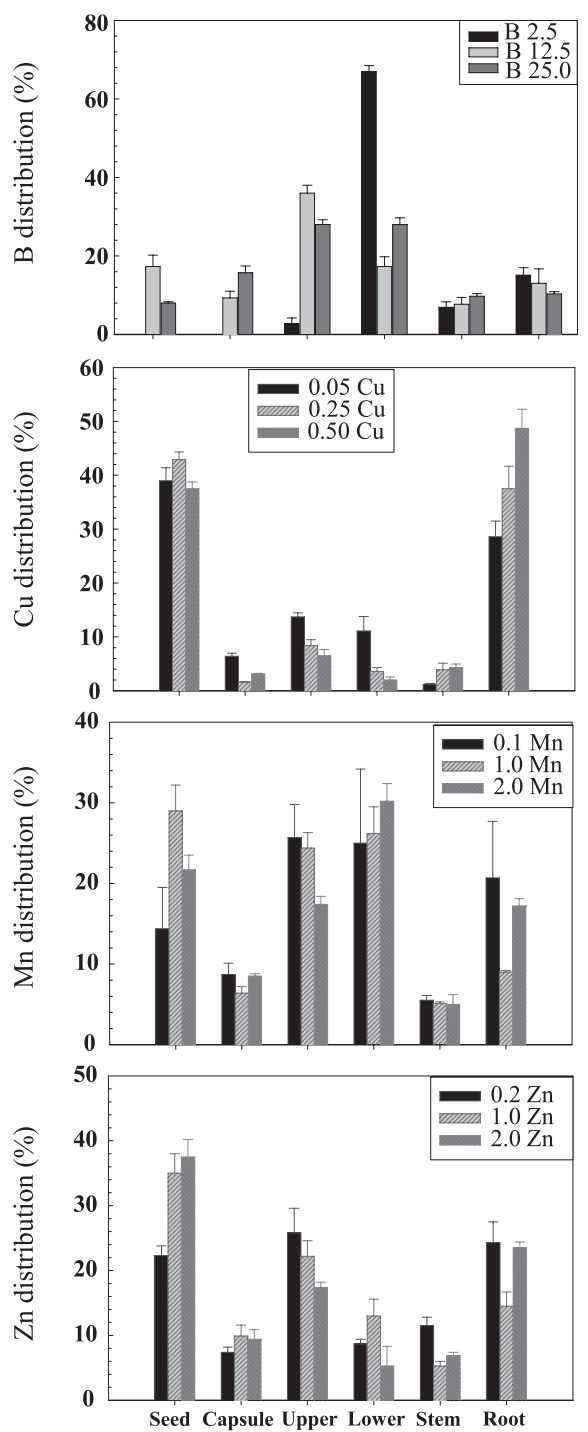

Figure 2. Uptake and distribution of boron, copper, manganese and zinc in the components of the shoot and root, considering the levels $\left(\mu \mathrm{mol} \mathrm{L} \mathrm{L}^{-1}\right)$ of $\mathrm{B}, \mathrm{Cu}, \mathrm{Mn}$ and $\mathrm{Zn}$ to castor bean hybrid "Iris" grown in a nutrient solution. Bars represent the standard error of the mean. 
levels were found in the lower leaves, except at the highest $\mathrm{Zn}$ level, in which case the roots and upper leaves contained the highest levels.

The highest $\mathrm{B}$ concentrations were found in the upper (recently expanded) and lower leaves (mature) in the plants grown at B levels of 12.5 and $25 \mu \mathrm{mol} \mathrm{L} \mathrm{L}^{-1}$, respectively. In contrast, the inflorescence of the deficient plants was the part that contained the lowest $\mathrm{B}$ concentrations. At the lowest $B$ level, the visual symptoms of B deficiency occurred in the following order on the plant tissues: leaves with marked symptoms (newest leaves); leaves with moderate symptoms (recently expanded leaves) and leaves without symptoms (mature leaves), at the respective levels of $\mathrm{B}$ of $0.7,3.8$ and $13.8 \mathrm{mg} \mathrm{kg}^{-1}$ (Table 3).

At the highest B level, the (lower and upper) leaves were the parts with the highest accumulation (351.8 $\mu \mathrm{g} / \mathrm{plant}$ ), corresponding to $56 \%$ of the total amount absorbed by the plants (Figure 2). Under moderate deficiency (B level of $12.5 \mu \mathrm{mol} \mathrm{L}^{-1}$ in the solution), the upper and lower leaves also absorbed most of the element, approximately $53 \%$ of the total $(201.9 \mu \mathrm{g} /$ plant). The fruits (seeds plus capsules), with adequate and moderate B supply, accumulated $24 \%(151.2 \mu \mathrm{g} / \mathrm{plant})$ and $27 \%$ $(100.0 \mu \mathrm{g} /$ plant $)$ of the total amount accumulated by the plants, respectively. It is known that the long-distance transport of $\mathrm{B}$ in plants is influenced by the transpiration flow in the xylem, and the more developed this organ is, the greater will be the leaf area or presence of stomata and consequently the higher the transpiration rate (Silva et al., 2008; Eichert \& Goldbach, 2010), possibly explaining these results. Moreover, it is worth noting the differences in the B accumulation between seed and capsule in both treatments (Figure 2). Under moderate deficiency, the seeds accumulated more B than in well-nourished plants, but under adequate B supply, the capsules accumulated more than the seeds.
The highest $\mathrm{Cu}$ accumulation was found in the roots and seeds, in all treatments. At the highest level, the roots and seeds accumulated approximately 197 and $157 \mu \mathrm{g} /$ plant, respectively, together accounting for $85 \%$ of the total $\mathrm{Cu}$ absorbed by the plants. Under marked $\mathrm{Cu}$ deficiency, these parts also accumulated most $\mathrm{Cu}$, around $70 \%$ of the total $(\approx 23$ and $32 \mu \mathrm{g} /$ plant $)$. In contrast, $\mathrm{Cu}$ accumulated in the lower leaves was identical in all treatments (Figure 2), which can be explained partly by the genetic control of $\mathrm{Cu}$ transport from the roots to the leaves (Sudo et al., 2008). However, the higher capacity of remobilization or redistribution of $\mathrm{Cu}$ and $\mathrm{Zn}$ from plant organs to the grains or seeds (strong sinks) than of Fe and $\mathrm{Mn}$ is widely reported in the literature, e.g., by Garnett \& Graham (2005).

There were differences in Mn uptake and distribution among the plant parts in function of the treatments. The amount of Mn accumulated in the plants increased as the level in the nutrient solution did. At the highest Mn level, $48 \%$ of the total amount taken up by the plants was transported to the lower and upper leaves (long-distance transport), followed by the seeds and roots, which accumulated 22 and $17 \%$ of the total, respectively. In turn, at the intermediate and lowest Mn levels, the behavior was virtually identical, that is, $51 \%$ was transported to the leaves. Considering the distribution between the shoots and roots, in the average for all treatments, $84 \%$ was transported to the shoot, where the leaves (upper and lower together) were the main $\mathrm{Mn}$ accumulating organs (Figure 2). In this respect, the leaf blades are the main part of the plant involved in light interception and photosynthesis, where $\mathrm{Mn}$ is involved in the partitioning of water molecules and evolution of $\mathrm{O}_{2}$ during photosynthesis (water photosynthesis or Hill's reaction) in the luminous phase, with transfer of electrons from photosystem II to photosystem I (Pedas et al., 2005; Kering et al., 2009). The long-distance transport of Mn to the

Table 3. Boron concentration in parts of the castor bean hybrid "Iris", grown in a complete nutrient solution and with levels of $B$

\begin{tabular}{|c|c|c|c|c|c|c|}
\hline Level & Root & Stem & Lower Leaf & Upper Leaf & Capsule & Seed \\
\hline$\mu \mathrm{mol} \mathrm{L} \mathrm{L}^{-1}$ & \multicolumn{6}{|c|}{$-\mathrm{mg} \mathrm{kg}^{-1}$} \\
\hline 12.5 & $6.8 \mathrm{bB}$ & $4.1 \mathrm{Bc}$ & $21.1 \mathrm{bA}$ & $19.2 \mathrm{bA}$ & $6.1 \mathrm{bBC}$ & $5.1 \mathrm{aBC}$ \\
\hline 25.0 & $10.8 \mathrm{aD}$ & $10.2 \mathrm{Ad}$ & $30.5 \mathrm{aB}$ & $35.1 \mathrm{aA}$ & $15.9 \mathrm{aC}$ & $4.2 \mathrm{aE}$ \\
\hline \multirow[t]{2}{*}{ CV (\%) } & 2.8 & 7.5 & 9.7 & 2.4 & 10.8 & 10.9 \\
\hline & Root & Stem & Leaf AS & Leaf MS & Leaf NS & Inflorescence \\
\hline 2.5 & $2.4 \mathrm{BC}$ & $1.5 \mathrm{CD}$ & $0.7 \mathrm{CD}$ & $3.8 \mathrm{~B}$ & $13.8^{\mathrm{a}}$ & $0.2 \mathrm{D}$ \\
\hline
\end{tabular}

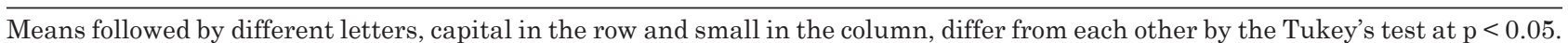
Leaf AS: leaves with marked symptoms. Leaf MS: leaves with moderate symptoms. Leaf NS: leaves without symptoms. 
seeds in the deficient, intermediate and complete treatments corresponded, respectively, to 14,29 and $22 \%$ of the total absorbed Mn by the plants (Figure 2).

At the highest $\mathrm{Zn}$ level, the seeds and roots accumulated the highest quantities (Figure 2), together accounting for $61 \%$ of the total $\mathrm{Zn}$ taken up by castor bean plants $(1,671 \mu \mathrm{g} / \mathrm{plant})$. In the complete treatment, $22 \%$ of the total $\mathrm{Zn}$ absorbed was carried to the leaves. However, in the treatments with moderate and marked deficiency, these transported amounts were 35 and $31 \%$ of the total absorbed amounts, respectively. With respect to the Zn-distribution between the shoots and roots, 77, 86 and $76 \%$ of the total taken up was transported to the shoots, respectively, for the complete, intermediate and deficient treatments. Also, the seeds produced by the plants supplied with 1.0 and $2.0 \mu \mathrm{mol} \mathrm{L}^{-1} \mathrm{Zn}$ were strong sinks. Finally, at low Zn availability, the $\mathrm{Zn}$-distribution among the seeds, upper leaves and roots was similar, corresponding to 22,25 and $24 \%$ of the total $\mathrm{Zn}$ absorbed $(743.9 \mu \mathrm{g} /$ plant$)$, respectively (Figure 2 ).

\section{CONCLUSIONS}

1. The first visual deficiency symptoms on castor bean hybrid "Iris" were observed for B and Zn, followed by $\mathrm{Cu}$ and $\mathrm{Mn}$.

2. The chloroplasts were the most affected cell ultrastructures by deficiencies of $\mathrm{Cu}, \mathrm{Mn}$ and $\mathrm{Zn}$, while the middle lamellae and cell walls were most sensitive to lack of $B$.

3. The dry matter yield of the shoots and roots was not affected by the treatments. However, B and Mn were the micronutrients that most affected the fruits, especially B.

4. Boron and Mn were mainly accumulated in the lower and upper leaves, while $\mathrm{Cu}$ and $\mathrm{Zn}$ were more concentrated in the roots and seeds of the castor bean hybrid "Iris".

\section{LITERATURE CITED}

ALMEIDA JR., A.B.; OLIVEIRA, F.A.; MEDEIROS, J.F.; OLIVEIRA, M.K.T. \& LINHARES, P.C.F. Efeito de doses de fósforo no desenvolvimento inicial da mamoneira. R. Caatinga, 22:217-221, 2009.

AZEVEDO, D.M.P.; BELTRÃO, N.E.M.; SEVERINO, L.S.; SANTOS, J.W. \& LEÃO, A.B. Rendimento e eficiência agronômica do consórcio da mamoneira com cereais e feijão caupi no semi-árido nordestino. R. Bras. Oleag. Fibros., 11:145-162, 2007.
BARON, M.; ARELLANO, J.B. \& GORGE, J.L. Copper and photosystem-II - A controversial relationship. Physiol. Plant., 94:174-180, 1995.

CHEN, W.; YANG, X.; HE, Z.; FENG, Y. \& HU, F. Differential changes in photosynthetic capacity, $77 \mathrm{~K}$ chlorophyll fluorescence and chloroplast ultrastructure between Zn-efficient and $\mathrm{Zn}$-inefficient rice genotypes (Oryza sativa) under low zinc stress. Plant Physiol., 132:89-101, 2008.

CHIARADIA, J.J.; CHIBA, M.K.; ANDRADE, C.A.; OLIVEIRA, C. \& LAVORENTI, A. Produtividade e nutrição de mamona cultivada em área de reforma de canavial tratada com lodo de esgoto. R. Bras. Ci. Solo, 33:701-709, 2009.

DINIZ NETO, M.A.; TÁVORA, F.J.A.F.; CRISÓSTOMO, L.A. \& DINIZ, B.L.M.T. Adubação NPK e épocas de plantio para mamoneira. II - Componentes das fases vegetativas e reprodutivas. R. Ci.. Agron., 40:417-426, 2009.

EICHERT, T. \& GOLDBACH, H.E. Transpiration rate affects the mobility of foliar-applied boron in Ricinus communis L. cv. Impala. Plant Soil, 328:165-174, 2010.

EPSTEIN, E. \& BLOOM, A.J. Mineral nutrition of plants: Principles and perspectives. 2.ed. Sunderland, Sinauer, 2005. 400p.

GARNETT, T.P. \& GRAHAM, R.D. Distribution and remobilization of iron and copper in wheat. Ann. Bot., 95:817-826, 2005.

GUPTA, U.C. Yield response to boron and factors affecting its uptake by crops. In: SINGH, K.; MORI, S. \& WELCH, R.M., eds. Perspectives on the micronutrient nutrition of crops. Jodhpur, Scientific Publishers, 2001. p.91-118.

HOCKING, P.J. Accumulation and distribution of nutrients in fruits of castor bean (Ricinus communis L.). Ann. Bot., 49:51-62, 1982.

KERING, M.K.; LUKASZEWSKA, K. \& BLEVINS, D.G. Manganese requirement for optimum photosynthesis and growth in NAD-malic enzyme C-4 species. Plant Soil, 316:217-226, 2009.

LANGE, A.; MARTINES, A.M.; SILVA, M.A.C.; SORREANO, M.C.M.; CABRAL, C.P. \& MALAVOLTA, E. Efeito de deficiência de micronutrientes no estado nutricional da mamoneira cultivar Iris. Pesq. Agropec. Bras., 40:61-67, 2005.

LAVRES JR, J.; NOGUEIRA, T.A.R.; CABRAL, C.P. \& MALAVOLTA, E. Deficiências de macronutrientes no crescimento e na produção da mamoneira cultivar Iris. R. Bras. Ci. Agr., 4:405-413, 2009.

LAVRES JR., J.; REIS, A.R.; ROSSI, M.L.; CABRAL, C.P.; NOGUEIRA, N.L. \& MALAVOLTA, E. Changes in the ultrastructure of three soybean cultivars in response to manganese supply in solution culture. Sci. Agric., 67:287$294,2010$.

LIMA, R.L.S.; SEVERINO, L.S.; FERREIRA, G.B.; SILVA, M.I.L.; ALBUQUERQUE, R.C. \& BELTRÃO, N.E.M. Crescimento da mamoneira em solo com alto teor de alumínio na presença e ausência de matéria orgânica. R. Bras. Oleag. Fibros., 11:15-21, 2007.

LOOMIS, W.D. \& DURST, R.W. Chemistry and biology of boron. Biofactors, 3:229-239, 1992. 
LUFT, J.H. Improvements in epoxy resin embedding methods. J. Biophys. Biochem. Cytol., 9:409-414, 1961.

MALAVOLTA, E. Manual de nutrição mineral de plantas. São Paulo, Agronômica Ceres, 2006. 631p.

MALAVOLTA, E.; MORAES, M.F.; LAVRES JR, J. \& MALAVOLTA, M. Micronutrientes e metais pesados - essencialidade e toxidez. In: PATERNIANI, E., ed. Ciência, agricultura e sociedade. Brasília, Embrapa Informação Tecnológica, 2006. p.117-154.

MALAVOLTA, E.; VITTI, G.C. \& OLIVEIRA, S.A. Avaliação do estado nutricional das plantas: princípios e aplicações. 2.ed. Piracicaba, POTAFOS, 1997. 319p.

MARSCHNER, H. Mineral nutrition of higher plants. London, Academic Press, 1995. 889p.

MENGEL, K. \& KIRKBY, E. Principles of plant nutrition. 5.ed. Dordrecht/Boston/London, Kluwer Academic Publishers, 2001. 849p.

NAKAGAWA, J. \& NEPTUNE, A.M.L. Marcha de absorção de nitrogênio, fósforo, potássio, cálcio e magnésio na cultura da mamoneira (Ricinus communis L.) cultivar "Campinas". An. ESALQ, 28:323-337, 1971.

PAPADAKIS, I.E.; GIANNAKOULA, A.; THERIOS, I.N.; BOSABALIDIS, A.M.; MOUSTAKAS, M. \& NASTOU, A. Mn-induced changes in leaf structure and chloroplast ultrastructure of Citrus volkamericana (L.) plants. J. Plant Physiol., 164:100-103, 2007.

PATERNIANI, E. Agricultura sustentável nos trópicos. Est. Av., 15:303-326, 2001.

PEDAS, P.; HEBBERN, C.A.; SCHJOERRING, J.K.; HOLM, P.E. \& HUSTED, S. Differential capacity for high-affinity manganese uptake contributes to differences between barley genotypes in tolerance to low manganese availability. Plant Physiol., 139:1411-1420, 2005.

REYNOLDS, E.S. The use of lead citrate at high $\mathrm{pH}$ as an electron opaque stain in electron microscopy. J. Cell Biol., 17:208-212, 1963.
SAHRAWAT, K.L.; WANI, S.P.; PARDHASARADHI, G. \& MURTHY, K.V.S. Diagnosis of secondary and micronutrient deficiencies and their management in rainfed agroecosystems: case study from Indian semi-arid tropics. Comm. Soil Sci. Plant Anal., 41:346-360, 2010.

SAS Institute Inc. SAS/STAT. User's Guide, version 8.0. Cary, 2000.

SEVERINO, L.S.; FERREIRA, G.B.; MORAES, C.R.A.; GONDIM, T.M.S.; FREIRE, W.S.A.; CASTRO, D.A.; CARDOSO, G.D. \& BELTRÃO, N.E.M. Crescimento e produtividade da mamoneira adubada com macronutrientes e micronutrientes. Pesq. Agropec. Bras., 41:563-568, 2006.

SILVA, D.H.; ROSSI, M.L.; BOARETTO, A.E.; NOGUEIRA, N.L. \& MURAOKA, T. Boron affects the growth and ultrastructure of castor bean plants. Sci. Agric., 65:659-664, 2008.

SILVA, T.R.B.; LEITE, V.E.; SILVA, A.R.B. \& VIANA, L.H. Adubação nitrogenada em cobertura na cultura da mamona em plantio direto. Pesq. Agropec. Bras.,42:1357-1359, 2007.

SMIRNOFF, N. Antioxidants and reactive oxygen species in plants. Oxford, Wiley-Blackwell Publisher, 2005. 302p.

STEWART, W.M.; DIBB, D.W.; JOHNSTON, A.E. \& SMYTH, T.J. The contribution of commercial fertilizer nutrients to food production. Agron. J., 97:1-6, 2005.

SUDO, E.; ITOUGA, M.; YOSHIDA-HATANAKA, K.; ONO, Y. \& SAKAKIBARA, H. Gene expression and sensitivity in response to copper stress in rice leaves. J. Exper. Bot., 59:3465-3474, 2008.

TAYLOR, P.G. \& TOWNSEND, A.R. Stoichiometric control of organic carbon-nitrate relationships from soils to the sea. Nature, 464:1178-1181, 2010.

VITOUSEK, P.M.; NAYLOR, R.; CREWS, T.; DAVID, M.B.; DRINKWATER, L.E.; HOLLAND, E.; JOHNES, P.J.; KATZENBERGER, J.; MARTINELLI, L.A.; MATSON, P.A.; NZIGUHEBA, G.; OJIMA, D.; PALM, C.A.; ROBERTSON, G.P.; SANCHEZ, P.A.; TOWNSEND, A.R. \& ZHANG, F.S. Nutrient imbalances in agricultural development. Science, 324:1519-1520, 2009. 